\title{
PENINGKATAN KETERAMPILAN MENULIS PARAGRAF MELALUI PENERAPAN KEGIATAN MENULIS JURNAL DAN PEMANFAATANNYA PADA SISWA KELAS VII MTS NEGERI KOTA TEBING TINGGI
}

\author{
Mariana \\ Surel : marianaspd510@gmail.com
}

\begin{abstract}
ABSTRAK
Pendekatan yang digunakan dalam penelitian ini adalah pendekatan kualitatif, sedangkan rancangan penelitian yang digunakan adalah penelitian tindakan kelas. Rancangan penelitian tindakan kelas tersebut dilakukan dalam tiga siklus penelitian. Subjek penelitiannya adalah siswa Kelas VII MTs N Tebing Tinggi. Hasil penelitian menunjukkan bahwa kegiatan tersebut dapat meningkatkan keterampilan menulis paragraf siswa, baik dari segi kuantitas maupun kualitas paragraf yang dihasilkan. Bimbingan dan arahan guru itu tetap diberikan, meskipun menulis jurnal adalah kegiatan menulis yang bersifat informal. Berdasarkan pembahasan hasil penelitian disarankan kepada guru bahasa Indonesia sebaiknya kegiatan pembiasaan menulis jurnal terus diterapkan dan dilakukan dengan disertai bimbingan yang intensif dan terarah. Dengan mencermati isi tulisan siswa, disarankan pula kepada guru mata pelajaran lain sebaiknya kegiatan menulis jurnal ini dapat diterapkan karena selain melatih keterampilan menulis paragraf, jurnal juga dapat mengkomunikasikan serta merefleksikan hasil belajar dan perkembangan pribadi siswa.
\end{abstract}

Kata Kunci : Menulis Paragraf, Menulis Jurnal, Penilaian Autentik

\section{PENDAHULUAN}

Pembelajaran

bahasa

Indonesia secara fungsional dan komunikatif adalah pembelajaran yang lebih menekankan siswa untuk belaajar berbahasa, dalam kaitannya dengan fungsi bahasa sebagai alat untuk berkomunikasi. Siswa bukan sekedar belajar tentang pengetahuan bahasa, melainkan belajar menggunakan bahasa untuk keperluan berkomunikasi. Untuk itu, pendekatan pembelajaran yang sesuai adalah pendekatan komunikatif.

Pembelajaran bahasa Indonesia dengan pendekatan komunikatif itu diarahkan untuk membentuk kompetensi komunikatif, yakni kompetensi kemampuan untuk menggunakan bahasa Indonesia sebagai alat komunikasi, baik pada aspek pemahaman, aspek penggunaan, maupun aspek apresiasi (Suparno 2001). Hal tersebut diatas berarti, melalui pembelajaran bahasa Indonesia diharapkan siswa memiliki kemampuan untuk menangkap makna dari sebuah pesan atau informasi yang disampaikan serta memiliki kemampuan untuk menalar dan mengemukakan kembali pesan atau informasi yang diterimanya itu. Siswa juga diharapkan memiliki kemampuan untuk mengekpresikan berbagai pikiran, gagasan, pendapat, 

dan perasaan dengan menggunakan bahasa yang baik. Kompetensi komunikatif itu dapat dicapai melalui proses pemahiran yang dilatihkan dan dialami dalam kegiatan pembelajaran. Salah satu aspek keterampilan berbahasa yang berkaitan dengan pengungkapan pikiran, gagasan, pendapat, dan perasaan tersebut adalah keterampilan menulis paragraf. Keterampilan menulis paragraf sebagai keterampilan berbagasa yang bersifat produktif-aktif merupakan salah satu kompetensi dasar berbahasa yang harus dimiliki siswa agar terampil berkomunikasi secara tertulis. Siswa akan terampil mengorganisasikan gagasan dengan runtut, menggunakan kosakata yang tepat dan sesuai, memperhatikan ejaan dan tanda baca yang benar, serta menggunakan ragam kalimat yang variatif dalam menulis jika memiliki kompetensi menulis paragraf yang baik.

Permasalahan pokok yang menjadi fokus penelitian ini adalah rendahnya keterampilan menulis paragraf siswa Kelas VII MTs N Tebing Tinggi. dari studi awal yang dilakukan di sekolah itu, ditemukan beberapa indikator yang menunjukkan rendahnya keterampilan menulis siswa di sekolah tersebut. Indikator yang dapat dilihat dari hasil tulisan siswa adalah (1) gagasan utama yang disajikan tidak jelas dan banyak paragraf yang memiliki lebih dari satu gagasan utama, (2) gagasan pengembang yang disajikan tidak padu dan tidak mendukung gagasan utama, (3) banyak paragraf yang hanya terdiri dari atau kalimat, (4) kalimat-kalimat yang digunakan banyak yang memiliki struktur yang tidak tepat, (5) pilihan kata yang digunakan masih terbatas dan kurang tepat, utamanya pada penggunaan konjungsi, dan (6) tanda baca dan ejaan yang digunakan masih banyak kesalahan. Berdasarkan indikatorindikator tersebut hasil tulisan diposisikan pada kualifikasi kurang sampai dengan cukup.

Berdasarkan latar belakang dan fokus masalah, maka masalah dalam penelitian ini secara umum adalah "bagaimaanakah upaya meningkatkan keterampilan menulis paragraf siswa Kelas VII MTs N Tebing Tinggi melalui penerapan kegiatan menulis jurnal dan pemanfaatannya untuk penilaian autentik?". Rumusan masalah umum itu dirinci meniadi tiga masalah khusus. Ketiga masalah khusus tersebut adalah sebagai berikut: Bagaimanakah upaya meningkatkan keterampilan menulis paragraf siswa Kelas VII MTs N Tebing Tinggi melalui tindakan pemahaman konsep dan pemodelan kegiatan menulis jurnal? Bagaimanakah upava meningkatkan keterampilan menulis paragraf siswa Kelas VII MTs N Tebing Tinggi melalui tindakan pelaksanaan dan pembiasaan kegiatan menulis jurnal dalam pembelajaran? Bagaimanakah upaya meningkatkan keterampilan menulis paragraf siswa Kelas VII MTs N Tebing Tinggi melalui tindakan 
penilaian autentik dengan memanfaatkan tuiisan-tulisan dalam jurn, al siswa.

Secara umum tujuan penelitian ini adalah mcndapatkan kajian tentang upaya meningkatkan keterampilan memalis paragraf siswa Kelas VII MTs N Tebing Tinggi Malang melalui kegiatan menulis jurnal dan pemanfaatannva untuk penilaian autentik. Tujuan penelitian umum itu diuraikan secara khusus sebagai berikut: Mendapatkan kajian tentang upaya meningkatkan keterampilan menulis paragraf siswa Kelas VII MTs N Tebing Tinggi melalui tindakan pemahaman konsep dan pemodelan. Mendapatkan kajian tentang upaya meningkatkan keterampilan menulis paragraf siswa Kelas VII MTs N Tebing Tinggi melalui tindakan pelaksanaan dan pembiasaan menulis jurnal dalam pembelajaran. Mendapatkan kajian tentang upaya meningkatkan keterampilan menulis paragraf siswa Kelas VII MTs N Tebing Tinggi melalui tindakan penilaian autentik dengan memanfaatkan tulisan-tulisan dalam jurnal siswa.

\section{METODE PENELITIAN}

Salah satu model atau perangkat penilaian autentik dalam pembelajaran keterampilan menulis yang dapat dilakukan adalah memanfaatkan tulisan dalam jurnal siswa. Jurnal dapat menjadi sebuah afternatif bahan penilaian yang efektif untuk mengetahui dan melihat perkembangan keterampilan menulis siswa. Jurnal siswa dapat menjadi bagian dari portofoiio yang merekam perkembangan menulis dari waktu ke waktu. Selain itu, pemanfaatan jurnal dalam penilaian menjadikan penilaian tidak hanya dilakukan guru, tetapi siswa juga dapat dilatih untuk melakukan penilaian dirisendiri (self-assesment) terhadap tulisan-tulisan yang telah dibuatnya. Siswa juga dapat memilih sebuah tulisan andalan dalam jurnal yang ditulisnya untuk dinilai atau ditanggapi oleh temannva (peerassesment). Bahkan bila siswa tidak keberatan, orangtuanya pun dapat membaca dan memberikan penilaian terhadap tulisan-tulisan dalam jurnal itu.

Melalui kegiatan ini siswa dapat berpikir kritis, mengamati, menemukan kesaiahannya sendiri kemudian berupava membuat tulisan yang lebih baik. Bila kegiatan ini dapat dilakukan secara efektif dan optimal, maka diharapkan keterampilan menulis siswa, khususnya keterampilan menulis paragraf dapat meningkat. Proses penilaian dan pembelajaran menulis pun menjadi lebih bermakna hagi siswa.

Subjek penelitian ini adalah siswa Kelas VII MTs N Tebing Tinggi. Seluruh siswa akan dikenai tindakan karena penelitian tindakan kelas adalah penelitian yang mengikuti alur pembelajaran sebenarnva. Pertimbangan pemilihan Kelas VII sebagai sumber data penelitian karena Kelas VII A merupakan kelas peneliti dalam melaksanakan tugas sehari-hari dan 
di kelas ini terdapat masalah tersebut. Selain itu, Kelas VII SMP merupakan kelas tengah, dengan siswa yang telah dapat herpikir secara logis dan abstrak serta telah mempunvai dasar pengetahuan awal tentang keterampilan menulis yang dipelajari di kelas VII. Pengetahuan awal tersebut, misalnya bentuk paragraf, pola-pola kalimat, dan penggunaan ejaan atau pungtuasi.

\section{HASIL PENELITIAN DAN PEMBAHASAN}

Data yang ingin diperoleh adalah data tentang proses kegiatan dan data tentang hasil kegiatan menulis jurnal. Data-data itu meliputi (1 ) data awal tentang kemampuan kcterampilan menulis paragraf siswa (2) data pokok tentang upaya peningkatan keterampilan menulis paragraf melalui tindakan pemahaman konsep dan pemodelan kegiatan menulis jurnal. (3) data pokok tentang upaya peningkatan keterampilan menulis paragraf melalui tindakan pelaksanaan dan pembiasaan kegiatan menulis jurna1, (4) data pokok tentang upaya peningkatan keterampilan menulis paragraf melalui tindakan penilaian autentik dengan memanfaatkan tutisan $\neg$ tulisan dalam jurnal siswa, serta (S) data pendukung tentang perkembangan keterampilan menulis siswa setelah tindakan. Untuk memperoleh data penelitian, teknik pengumpulan data yang akan digunakan adalah wawancara, pengamatan, pendokumentasian. dan pemberian tes menulis. Sesuai dengan (karakteristik penelitian kualitatif, dalam penelitian ini peneliti berperan sebagai instrumen utama pengumpulan data. Data-data tersebut berupa transkrip wawancara dan rekaman kegiatan belajar, catatan lapangan dokumentasi hasil tulisan siswa dan hasil tes Menulis.

Analisis data dalam penelitian ini akan dilakukan dengan dasar analisis data model alir yang terdiri atas tiga tahapan yaitu (1) mereduksi data, (2) menyajikan data, dan (3) menarik kesimpulan dan memverifikasi. Analisis data tersebut dilakukan selama dan sesudah penelitian, mulai dari tahap perencanaan kegiatan, pelaksanaan. Hingga refleksi kegiatan.

Sesuai perencanaan yang telah dibuat tindakan pembelajaran dikembangkan dalam tiga siklus tindakan. Perencanaan yang dibuat, disesuaikan dengan satuan program semester yang telah disusun oleh guru mata pelajaran, sehingga pelaksaaaan penelitian ini tetap berjalan sesuai alur progam pembelajaran mata pelajaran bahasa Indonesia sebagaimana mestinya. kegiatan menulis jurnal dalam penelitian ini menjadi kegiatan suplemen vang terintegrasi dalam pembeiajaran pokok.

Pelaksanaan setiap siklus terdiri atas tiga tindakan pokok. Adapun ketiga tindakan pokok tersebut adalah (1) pemahaman dan pemodelan. (2) Pelaksanaan dan pembiasaan kegiatan menulis jurnal, dan (3) pelaksanaan penilaian autentik melalui jurnal. Dalam tiap 
siklus, tindakan pertama dilaksanakan dengan alokasi waktu dua kali pertemuan jam pelajaran. Tindakan kedua dilakukan terinteigrasi dalam tiap jam pelajaran bahasa Indonesia selama empat kali pertemuan, guru menyediakan waktu sepuluh sampai dengan lima belas menit di menit awal atau di akhir pelajaran untuk menulis. Materi tulisan jurnal disesuaikan dengan konteks materi pembelajaran saat itu. Tindakan ketiga selain dilakukan secara bersinambungan oleh yang, dilakukan pula oleh siswa sekitar dua puluh menit pada waktu yang ditentukan. Setiap siklus siswa menulis jurnal sebanvak lima kali.

Dalam kegiatan peanahaman konsep dan permodelan ini guru melakukan langkah-langkah pokok dalam pembeiajaran. langkahlangkah tersebut, yaitu menyampaikan tujuan dan pokokpokok kegiatan pembelajaran. (2) membangkitkan skemata siswa. (3) menjelaskan dan mendiskusikan tentang mcnulis paragraf yang baik, (4) memberikan latihan dan contoh penulisan paragraf yang baik, (5) menghubungkan kegiatan menulis paragraf dengan menulis jurnal, (6) mendiskusikan dan menjelaskan tentang kegiatan menulis jurnal. (7) memajankan contoh-contoh jurnal sebagai model serta (8) menulis jurnal tahap awal dengan mengamati model yang disajikan. Melalui kegiatan-kegiaian itu, sisa manipu mengkontruksi sendiri konsep penngetahuannya tentang menulis paragraf dengan pola pengembangan yang baik.

Pada siklus I kegiatan yang dilakukan pada tahap ini ada 6 langkah pokok. Keenam langkah pokok itu adalah ( 1 ) menyediakan waktu di awal pembelajaran untuk menulis, (2) meminta siswa menulis secara bebas tentang gagasan. Perasaan, atau berbagai hal yang dialaminya, (3) membantu memunculkan gagasan siswa melalui kegitan tanya jawab, (4) memantau dan membimbing siswa saat menulis. (5) memberi penguatan tiap kali perternuan, dan (6) mengumpulkan kembali buku jurnal yang telah ditulis untuk diberi respon

\section{Pembahasan}

Hasil penelitaan tindakan ini menunjukkan bahwa dengan pembiasaan menulis jurnal secara berkelanjutan, siswa menjadi terbiasa menulis paragraf dan keterampilan menulis paragrafnya pun meningkat. Indikator peningkatan keterampiian menulis paragraf tersebut dapat dilihat dari tiga hal yaitu (1) kuantitas gagasan yang dihasilkan, (2) kualitas paragraf: dan i:cantus asan aktivitas dan motivasi siswa.

Peningkatan pertama terlihat dari jumlah gagasan dan pilihan topik. Jumlah gagasan yang ditulis bertambah banyak serta memperlihatkan cara pemalu yang beragam, tidak datemukan lagi paragraf yang hanya terdiri dari satu kalimat. Peningkatan tersebut teriadi pada tiap siklus tindakan. 
Dari data di atas dapat dijelaskan siklus I kualitas paragraf siswa rata-rata berkualitas cukup, cukup maka pada siklus II dan III meningkat menjadi baik. Dengan kata lain, paragraf yang ditulis siswa umumnya telah memiliki gagasan utama dan gagasan pengembang yang jelas. Gagasan-gagasan itu dikembangkan secara logis dengan pengorganisasian yang baik. Struktur kalimat dan peralihan antar gagasan dalam paragraf sudah memperlihatkan keefektifan, hal tersebut teriihat dari sedikitnya kesalahan dalam penggunaan konjungsi. Kosa-kata yang digunakan juga cukup tepat dan dapat mewakiii gagasan yang dikemukakan. Beberapa kesalahan tata bahasa dari mekanik tulisan masih diketemukan, tetapi tidak banyak dan tidak sampai mengaburkan makna gagasan yang dikemukakan.

\section{Persentase Keaktifan Siswa Selama Pelaksanaan Tindakan}

\begin{tabular}{|c|c|c|c|}
\hline Indikator & $\begin{array}{l}\text { Siklus } \\
\text { I }\end{array}$ & $\begin{array}{l}\text { Siklus } \\
\text { II }\end{array}$ & $\begin{array}{l}\text { Siklus } \\
\text { III }\end{array}$ \\
\hline $\begin{array}{l}\text { sangat } \\
\text { aktif } \\
\text { menulis }\end{array}$ & $2(8 \%)$ & $\begin{array}{l}4 \\
(24 \%)\end{array}$ & $\begin{array}{l}8 \\
(32 \%)\end{array}$ \\
\hline $\begin{array}{l}\text { aktif } \\
\text { menulis }\end{array}$ & $\begin{array}{l}9 \\
(36 \%)\end{array}$ & $\begin{array}{l}12 \\
(48 \%)\end{array}$ & $\begin{array}{l}14 \\
(66 \%)\end{array}$ \\
\hline $\begin{array}{l}\text { kurang } \\
\text { aktif } \\
\text { menulis }\end{array}$ & $\begin{array}{l}8 \\
(32 \%)\end{array}$ & $\begin{array}{l}4 \\
(16 \%)\end{array}$ & $\begin{array}{l}3 \\
(12 \%)\end{array}$ \\
\hline pasif & $\begin{array}{l}6 \\
(24 \%) \\
\end{array}$ & $\begin{array}{l}3 \\
(12 \%) \\
\end{array}$ & - \\
\hline Jumlah & $\begin{array}{l}25 \\
(100 \%)\end{array}$ & $\begin{array}{l}25 \\
(100 \%)\end{array}$ & $\begin{array}{l}25 \\
(100 \%)\end{array}$ \\
\hline
\end{tabular}

Dari tabel di atas terlihat terjadi peningkatan aktivitas siswa selama pelaksanaan tindakan. Pada siklus I masih banyak siswa yang belum atau kurang aktif untuk menilis. Namun, pada siklus II dan III jumlah siswa yang aktif dan sangat aktif menulis terus meningkat. Bahkan, pada akhir siklus III tidak terlihat siswa yang pasif atau tidak menulis jurnalnya.

Peningkatan tersebut dapat tercapai karena bimbingan Guru yang diberikan secara dinamis dan tidak prosedural. Sekalipun menulis jurnal bersifat menulis informai. tetapi bimbingan tetap diberikan sehingga dapat menggali ide-ide kreatif siswa dalam menentukan topik dan mengemukakan gagasan. Guru jug berupaya mengaitkan kegiatan menulis jurnal tersehut dengan konteks kehidupan atau materi pembelaiaran sehingga gagasan yang ditulis dapat merefleksikan perkembangan hasil belajar dan perkembangan pribadi siswa. Selain itu, respon tertulis vang, diberikan yang ternyata mampu meningkatkan motivasi untuk menulis. Motivasi itu tumbuh karena siswa merasa guru menghargai dan peduli dengan apa vang ditulisnya.

Pada awal pembiasaan menulis jurnal, siswa banyak membutuhkan waktu untuk menghasilkan sebuah paragraf. tetapi setelah beberapa kali menulis siswa menjadi semakin terampil. Bahkan dalam perkembangannya siswa mau membuat buram tulisannya di rumah, 
meskipun guru tidak menugaskan ha1 itu. Dampaknya, pemberian waktu sepuluh sampai lima beias menit yang awalnya terkesan mengurangi waktu pembelajaran pokok dapat dimanfaatkan secara efektif, menjadi berharga, dan lebih bermakna dalam upaya melatih keterampilan menulis siswa.

Dampak positif lain yang ditemukan dari pembiasaan menulis jurnal adalah tumbuhnya kemauan dan keterbukaan siswa untuk mengkomunikasikan atau mengekspresikan secara tertulis berbagai masalah atau peristiwa yang dialami. Selain itu, kehbngungan siswa menentukan topik atau kalimat pertama saat mulai menulis dapat teratasi melalui pembiasaan menulis jurnal. Penilaian autentik ini juga mendorong siswa untuk mengkonstruksi sendiri pengetahuannya tentang kaidahkaidah teknik penulisan yang benar karena siswa belajar dari mencermati, mengidentifikasi kesalahan-kesalahan dalam tulisan, dan memperbaiki kesalahankesalahan tersehut. Kemampuan mengidentifikasi berbagai kesalahan tersebut mendorong siswa untuk menulis paragrah secara lebih cermat sehingga tidak mengulangi kesalahan serupa saat menulis paragraf dalam jurnal berikutnya. Di sisi lain, semangat kerja sama dan percaya diri siswa semakin terbangun melalui kegiatan ini. Siswa belajar untuk bersikap jujur dan berani menilai serta menghargai hasil pekerjaannya sendiri maupun pekerjaan temannya.

\section{SIMPULAN}

Salah satu permasalahan yang dihadapi dalam pembelajaran bahasa Indonesia di sekolah adalah rendahnva keterampilan menuiis paragraf siswa. Hal itu terlihat dari rendahnva kualitas paragraf yang dihasilkan siswa. Siswa juga kurang antusias dan mengalami kesulitan ketika mendapat tugas untuk menulis. Hal tersebut diindikasikan karena pembelajaran menulis yang dilakukan belum mendorong dan membentuk kebiasaaan siswa untak menulis. Pembelajaran menulis yang disajikan belum memberi kesempatan banyak pada siswa untuk menulis. Di sisi lain penilaian keterampilan menulis juga belum dilakukan secara komprehensif dan berkesinambungan. Untuk mengatasi permasalahan tersebut; salah satu alternatif tindakan yang dapat diterapkan adalah penerapan kegiatan menulis jurnal dan memanfaatkan hasil tulisan siswa dalam jurnal untuk penilaian autentik.

Penerapan kegiatan menuiis jurnai ini dapat memberikan kesempatan lebih banyak kepada siswa untuk mengekspresikan gagasan secara tertulis. Dengan terbiasa dan lebih sering menulis, kualitas paragraf-paragraf yang dihasilkan dapat semakin baik. Dengan, terbiasa menulis kreativitas siswa dalam menulis pun meningkat. Siswa semakin mudah dan terbiasa menemukan berbagai bahan atau gagasan yang dapat ditulisnya. 


\begin{abstract}
Penerapan autentik oleh siswa maupun guru dengan memanfaatkan hasil tulisan jurnal siswa juga dapat memberi pengaruh yang besar terhadap peningkatan keterampilan menulis paragraf siswa. Dengan menilai hasil tulisannya sendiri maupun hasil tulisan teman; siswa dapat mengkonstruksi dan menemukan sendiri pengetahuannya Siswa belajar dari berbagai kesalahan untuk menulis lebih baik. Di Sisi lain guru juga dapat memanfaatkan hasil autentik tulisan dalam jurnal siswa sebagai sumber informasi untuk melibat perkembangan belajar siswa. Dalam pelaksanaannya. kegiatan menulis jurnal dan penilaian autentik tersebut dilakukan secara terpadu dan terintegrasi dengan kegiatan pokok pembelajaran bahasa lndonesia.
\end{abstract}

\section{DAFTAR RUJUKAN}

Depdikbud. 1999. Penelitian Tindakan (Action Research). Bahan Pelatihan Jakarta: Dikdasmen Depdikbud.

Depdiknas. 2003. Kurikulum 2004. Standar Kompetensi Mata Pelajaran Bahasa dan Sastra Indonesia SMP dan MTs (Draf Final). Jakarta: Depdiknas.

Capacchione. L. 1989. The Creative Journal For Children: A Guide for Parents, Teacher, and Counselors. Boston: Shambala. Eanes, R. 1997. Content Area Literacy: Teaching Today's and Tomorrow. New York: Delmar Publisher.
Elliot, J. 1991. AN. Action Reseach for Educational Change. Buckingham: Open University Press.

Laonhardt, M. 2001. 99 Cara Menjadikan Anak Anda Bergairah Menulis. Terjemahan oleh Eva Y. Nukman. 2001. Bandung Kaifa.

Nurhadi \& Senduk, A.G. 2003. Pembelajaran Kontekstual dan Penerapannya dalam KBK. Malang: Penerbit Universitas Negeri Malang.

O’Malley, J.M. \& Piece, L.V. 1996. Authentic Assessment for Ennglish Language Learners: Practical Approaches For Teachers. Virginia: AddisonWesley.

Puhl, C. 1997. Develop, Not Judge: Continuous Assesment in the ESL Classroom. English Teaching Forum, April 1997, pp 2-9.

Saukah, A. 1999. Prinsip Dasar Penilaian Pendidikan Bahasa. Bahasa dan Seni. Tahun 27, Nomor 1, Pebruari 1999, Hal; 19- 33.

Saukah, Ali. 2001. The Teaching Writing and Grammar. Bahasa dan Seni. Tahun 28, Nomor 2, Agustus 2000, Hal. 191-199.

Suparno, 2001. Pembelajaran Bahasa Indonesia dengan Pendekatan Kontekstual. Makalah disajikan pada Simposium di Wisma Jaya, Bogor. Direktorat SLTP, 
Mariana : Peningkatan Keterampilan Menulis ....

Dirjen Dikdasmen. November, 2001.

Suyanto, K.E. 2002. Authentic Assesment (Penilaian Otentik) dalam Pembelajaran Bahasa. Materi Pelatihan Calon Pelatih Pembelajaran Kontekstual Mata Pelajaran Bahasa Inggris Guru SLT di Malang.
Direktorat SLTP, Depdiknas. 2002.

Tompkins, G.E \& Hoskisson, K. 1991. Language Arts : Content and Teaching Strategis. New York: Macmillan.

Tompskin, G.E. 1994. Teaching Writing Balancing Process and Product. New York: Macmillan. 